Wildlife Biology, by Raymond F. Dasmann. John Wiley, 45s.

This is essentially a text book based on the author's courses at the University of California and Humboldt State College. It covers the wide field of wildlife management and the ecological principles on which this should be designed. There is an admirable account of the devastating destruction of wildlife and habitat in California from the time of the first settlement to the present century, and of modern efforts to salvage what is left. Later chapters are devoted to wildlife habitats, territory, methods of study, population dynamics and regulation of numbers, land use and ecological principles. Chapters are subdivided into sections-mortality, predation, breeding age, diseases, to take a random sample-so that the book is extremely easy to use. It is well indexed, has a good reference list for further reading, and the illustrations are adequate.

Although this is a text book, it is by no means dry, but full of good sense and comments which are very much to the point-"one difference between a field biologist and an interested layman is that the biologist carries a notebook and uses it"-and it ends with a sentiment which must appeal to all readers of ORYX: "the short term future of wild country and wild animals depends on the value which we attach to these things and our attitude towards paying the cost attached to their preservation."

The main emphasis is on North America but this is by no means exclusive, and the book will be of real value not only to students but to anyone who lacks formal training and is engaged in the task of conservation, whether of the diminutive nature reserves in Britain or the great national parks of other continents. It is a book to make one think. RENNIE BERE.

\title{
The Broads, by E. A. Ellis. Collins, 36s.
}

For the last 45 years Edward Ellis has been studying every aspect of the Norfolk Broads. His knowledge embraces a prodigious spectrum of the local natural history, and perhaps no one is better qualified to lead a team of experts in writing this book. It is, on the whole, a magnificently comprehensive work covering not only the fauna and flora but also the influence of man's activities. Particularly valuable is the chapter on the origin of the Broads by Drs. J. M. Lambert, J. N. Jennings and C. T. Smith, showing how their co-ordinated research has exposed that these lakes are not natural but the flooded pits of medieval turf-cutters. From the excellent maps in the appendix one can follow the progressive diminution of the Broads.

The ecological aspects of the flora are fully covered. There are interesting observations on fungi which parasitise specific plants and insects; the chapters on invertebrates include commendable sections on molluses and spiders, and there is a remarkably extensive list of Broadland insects. The black variety of the swallow-tail butterfly is mentioned, but there is no reference to the existence of melanic polymorphisms in certain moths which rest among reeds. Edward Ellis gives few details on the spread of the coypu, but he discusses at length the effect on the vegetation of this naturalised rodent that has all but eliminated cowbane, even though the plant is poisonous to most mammals. So high is the standard of John Markham's and Eric Hosking's photography, that one does not feel a need for colour plates (though one set of insect pictures is upside-down), but I did miss the attractive cover jacket which Clifford and Rosemary Ellis have designed for so many of the New Naturalist volumes.

The long delay in publishing has meant that some of the information is out of date, and three of the contributors have not lived to see their work in print. Nevertheless this book will add greatly to the appreciation which so many people already have for the Norfolk Broads. Let us hope that the essential co-existence of Man and Nature will continue in this region.

JAMES CADBURY. 